\title{
PERTANGGUNGJAWABAN PIDANA BANK DALAM PELANGGARAN KEGIATAN OPERASIONAL DIDASARKAN PADA UNDANG-UNDANG NOMOR 10 TAHUN 1998
}

Oleh:

\section{Johannes Ibrahim dan Hassanain Haykal}

\begin{abstract}
Banks are the intermediation institutions which have important role in economic of a nation. In order to supervise and monitor bankong activities, government has issued Law Number 10 of 1998 on amandement of Law Number 7 of 1992 on banking which is blogated compulsive to all banking stakeholders. This law regulates administrative and criminal sanctions. In accordance with criminal sanction, any action determine as a violation based on its offence related to any norm. This article will examine operational vilogation, which qualified as crime offence. This article also examine bank accountability for every violation statedabove.
\end{abstract}

Keywords: Criminal accountability, violation, operational activities.

\section{PENDAHULUAN}

Bank merupakan lembaga intermediasi keuangan yang didirikan dengan kewenangan untuk menerima simpanan uang, meminjamkan uang. Bank merupakan salah satu urat nadi perekonomian suatu negara, tanpa Bank masyarakat akan kesulitan untuk menabung, meminjam uang dan memperoleh tambahan modal usaha atau melakukan transaksi perdagangan Internasional secara efektif dan aman.

Guna meningkatkan fungsi kontrol sosial terhadap lembaga Perbankan yang mengelola uang masyarakat, pemerintah melakukan pengaturan, pembinaan dan pengawasan terhadap segala bentuk kegiatan perbankan dengan diberlakukannya UndangUndang Nomor 10 Tahun 1998 tentang Perubahan Atas Undang-Undang Nomor 7 Tahun 1992 tentan Perbankan. Pemberlakuan Undang-Undang Nomor 10
Tahun 1998 tentang Perubahan Atas Undang-Undang Nomor 7 Tahun 1992 tentang Perbankan menjadi payung hukum (umbrella act) bagi setiap kegiatan maupun aktivitas perbankan lainnya, di mana bisnis perbankan akan selalu berpedoman dan berlandaskan aturan hukum.

Tuntutan hukum terhadap bank dapat disebabkan oleh beberapa faktor, di mana salah satunya yaitu pelanggaran kegiatan operasional bank yang dikategorikan sebagai delik pidana. Lazimnya, suatu pelanggaran kegiatan operasional perbankan diselesaikan melalui jalur perdata maupun administrasi. Penyelesaian melalui jalur perdata didasarkan atas adanya hubungan kontraktual yang terjadi antara bank dengan nasabah, yang mana hubungan kontraktual sebagaimana dimaksud masuk pada ranah privat. Sedangkan penyelesaian melalui jalur administratif didasarkan pada rumusan 
norma yang tertuang dalam peraturan perundang-undangan, khususnya dalam Undang-Undang Nomor 10 Tahun 1998 tentang Perubahan Atas Undang-Undang Nomor 7 Tahun 1992 tentang Perbankan, yang menetapkan adanya ketentuan sanksi administratif. Namun di sisi lain, mengingat perbankan adalah lembaga yang mengelola dana masyarakat dan memiliki fungsi strategis dalam peningkatan perekonomian masyarakat, maka pemerintah mewajibkan perbankan untuk patuh dan taat dalam menjalankan setiap kebijakan pemerintah. Untuk itu, maka aspek publik dituangkan dalam substansi Undang-Undang Nomor 10 Tahun 1998 tentang Perubahan Atas Undang-Undang Nomor 7 Tahun 1992 tentang Perbankan, salah satunya yaitu adanya delik pidana. Problematika hukum yang timbul terkait adanya delik pidana sebagaimana dimaksud yaitu mengenai bagaimana suatu pelanggaran kegiatan operasional perbankan dapat dikategorikan sebagai delik pidana dan konsep pertanggungjawaban bank dalam pelanggaran kegiatan operasional berdasarkan Undang-Undang Nomor 10 Tahun 1998.

Metode Penelitian yang digunakan dalam penelitian ini adalah yuridis normatif dengan jenis penelitian hukum yang mengambil data kepustakaan dan didukung oleh data yang diperoleh di lapangan. Data yang digunakan dalam penelitian ini adalah data sekunder, yang terdiri atas bahan hukum primer, sekunder dan tersier. Melalui metode ini, tujuan yang hendak dicapai yaitu adanya hasil kajian tentang pelanggaran kegiatan operasional yang dapat dikualifikasikan sebagai delik pidana, serta pertanggungjawaban bank atas pelanggaran kegiatan operasional.

\section{PEMBAHASAN}

\section{Penetapan Delik Pidana Pada Pelanggaran Kegiatan Operasional Bank Pada Sistem Hukum Pidana Di Indonesia}

Bank memiliki fungsi dan peran yang strategis dalam peningkatan ekonomi masyarakat. Hal ini dapat dilihat dari kedudukan bank sebagai lembaga intermediasi, yang menghimpun dana dan menyalurkannya kembali kepada masyarakat dalam bentuk-bentuk lainnya. Peran dan fungsi intermediasi dari bank telah menghidupkan perputaran uang dari pihak yang kelebihan dana kepada pihak yang kekurangan dana. Dana yang dihimpun oleh bank merupakan dana masyarakat yang wajib dikelola dengan baik, serta dilindungi keberadaanya, sehingga tidak menimbulkan kerugian bagi para pihak, maupun bagi bank itu sendiri, yang pada akhirnya secara sistemik akan berdampak pada perekonomian negara.

Besarnya dampak yang ditimbulkan akibat pengelolaan bank yang tidak profesional, telah mendorong pemerintah melakukan tindakan preventif maupun represif melalui pengaturan bisnis perbankan. Secara normatif, pengaturan aktivitas perbankan tertuang dalam UndangUndang Nomor 10 Tahun 1998 juncto Undang-Undang Nomor 7 Tahun 1992 tentang Perbankan, dan peraturan perundang-undangan lainnya. Berdasarkan pengaturan tersebut, bank wajib melaksanakan kepatuhan terhadap pelbagai peraturan perundang-undangan dan menerapkan prinsip kehati-hatian 
(prudential banking regulation). Peraturan perundang-undangan yang mengatur aktivitas perbankan, khususnya UndangUndang Nomor 10 Tahun 1998 juncto Undang-Undang Nomor 7 Tahun 1992 tentang Perbankan telah mengatur perbuatan-perbuatan yang dilarang untuk dilakukan oleh bank maupun individu yang menjadi bagian dalam pengelolaan bank, dalam kegiatan operasionalnya. Sehingga apabila perbuatan tersebut tetap dilakukan, maka akan berdampak pada pengenaan sanksi pidana bagi si pelaku.

Sanksi pidana dikenakan kepada perbuatan-perbuatan yang dikategorikan sebagai tindak pidana. Menurut sistem KUHP Indonesia, tindak pidana dibagi menjadi kejahatan dan (misdrijven) sebagaimana diatur dalam dalam Buku II KUHP dan pelanggaran (overtredingen) diatur dalam Buku III KUHP. Hal ini secara tidak langsung menunjukkan bahwa sistem hukum pidana Indonesia telah membagi tindak pidana ke dalam 2 (dua) kategori tersebut. Undang-Undang Nomor 10 Tahun 1998 juncto Undang-Undang Nomor 1 Tahun 1992 tentang Perbankan, mengatur tentang perbuatan-perbuatan yang dikategorikan sebagai perbuatan pidana, baik kejahatan maupun pelanggaran. Hal ini dapat terlihat dari rumusan Pasal 51 Undang-Undang Nomor 10 Tahun 1998 juncto Undang-Undang Nomor 7 Tahun 1992 tentang Perbankan :

Pasal 51:

“(1) Tindak pidana sebagaimana dimaksud dalam Pasal 46, Pasal 47, Pasal 47A, Pasal 48 ayat (1), Pasal 49, Pasal 50, dan Pasal 50A adalah kejahatan."
(2) Tindak pidana sebagaimana dimaksud dalam Pasal 48 ayat (2) adalah pelanggaran."

Pada dasarnya dalam sistem hukum pidana, suatu perbuatan dinyatakan sebagai pelanggaran apabila dinyatakan demikian di dalam peraturan perundang-undangan. Hal ini berbeda dengan kejahatan, di mana suatu perbuatan dinyatakan sebagai suatu kejahatan apabila orang pada umumnya memandang bahwa pelaku-pelakunya itu memang pantas untuk dihukum, walaupun tindakan-tindakan tersebut oleh pembentuk undang-undang telah dinyatakan sebagai tindakan yang terlarang di dalam undangundang. Berdasarkan uraian di atas, perlu ditegaskan bahwa suatu perbuatan dinyatakan sebagai pelanggaran apabila perbuatan tersebut dengan secara tegas dinyatakan oleh undang-undang sebagai suatu pelanggaran, bukan kejahatan (ditetapkan oleh peraturan perundangundangan, bukan khalayak umum). (kursif penulis).

Tindakan atau perbuatan individu atau badan hukum dapat dikualifikasikan sebagai suatu perbuatan pelanggaran, apabila tindakan atau perbuatan tersebut memenuhi unsur-unsur sebagaimana dirumuskan dalam peraturan perundang-undangan, dalam hal ini Undang-Undang Nomor 10 Tahun 1998 tentang Perubahan Atas Undang-Undang Nomor 7 Tahun 1992 tentang Perbankan. Salah satu rumusan pasal yang terkait tindak pidana pelanggaran dalam pengelolaan bisnis perbankan dapat dilihat dalam Pasal 48 ayat (2), yang dipertegas oleh Pasal 51 ayat (2) Undang-Undang Nomor 10 Tahun 1998 tentang Perubahan Atas Undang- 
Udang Nomor 7 Tahun 1992 tentang Perbankan :

Pasal 48 ayat (2) :

"Anggota Dewan Komisaris, Direksi, atau pegawai bank yang lalai memberikan keterangan yang wajib dipenuhi sebagaimana dimaksud dalam Pasal 30 ayat (1) dan ayat (2) dan Pasal 34 ayat (1) dan ayat (2), diancam dengan pidana kurungan sekurang-kurangnya 1 (satu) tahun dan paling lama 2 (dua) tahun dan atau denda sekurang-kurangnya Rp1.000.000.000,00 (satu miliar rupiah) dan paling banyak Rp2.000.000.000,00 (dua miliar rupiah)."

Pasal 51 ayat (2) :

“ (2) Tindak pidana sebagaimana dimaksud dalam Pasal 48 ayat (2) adalah pelanggaran."

Berdasarkan isi pasal-pasal di atas dapat kita lihat bahwa uraian unsur delik dalam Undang-Undang tentang Perbankan mencakup:

a. Subjek hukum yang dapat dipertanggungjawabkan:

Barangsiapa : menujuk pada semua orang, sebagai subjek hukum yang cakap dan mampu bertanggungjawab, dalam hal ini Anggota Dewan Komisaris, Direksi, pegawai bank;

b. Unsur tindakan yang dilarang

Tindakan sebagaimana dimaksud, yaitu lalai memberikan keterangan yang wajib dipenuhi sebagaimana dimaksud dalam Pasal 30 ayat (1) dan ayat (2) dan Pasal 34 ayat (1) dan ayat (2).

c. Unsur sikap batin yang disyaratkan Bahwa di dalam Pasal 48 ayat (2) di atas, sikap batin yang disyaratkan berupa adanya kelalaian.

d. Sanksi yang diancamkan, berupa sanksi pidana penjara bagi pelaku (perorangan baik sebagai pribadi maupun sebagai perwakilan dari sebuah korporasi) dan / atau denda dapat dikenakan baik bagi perorangan ataupun bagi korporasi.

Berdasarkan pemaparan di atas, maka apabila individu atau organ bank memenuhi unsur tindak pidana sebagaimana diuraikan di atas, maka tindak pidana tersebut dikualifikasikan sebagai pelanggaran, yang tentunya akan dikenakan sanksi pidana terhadap pelaku. Namun demikian, untuk dapat dipidananya subjek hukum atas pelanggaran yang dibuatnya, maka subjek hukum tersebut harus memenuhi syarat pemidanaan, yaitu :

a. Syarat dari sudut pandang perbuatannya (syarat objektif)

1) Orang tsb melakukan suatu perbuatan (aktif/pasif); perbuatan yang dilakukan bersifat melanggar hukum.

2) Tidak ada alasan yang menghapus sifat melawan hukum (Alasan Pembenar).

b. Syarat dari sudut pandang pelakunya: (syarat subjektif)

1) Harus ada kemampuan bertanggung jawab/kesalahan dari pelakunya.

2) Tidak ada alasan / keadaan yang menghapus kemampuan 
bertanggung jawab tersebut (Alasan Pemaaf).

c. Pelaku melakukan perbuatan atas dasar kelalaian.

Berdasarkan uraian pembahasan di atas, ditemukan tolok ukur yang dipergunakan oleh Undang-undang Perbankan dalam mengkualifikasikan perbuatan sebagai pelanggaran. Sebagaimana dinyatakan dalam rumusan peraturan perundangundangan, mana pelaku, baik individu maupun organ bank memenuhi unsur-unsur yang telah ditetapkan. Unsur adanya kelalaian mengakibatkan suatu perbuatan tindak pidana perbankan dikategorikan sebagai pelanggaran. Sedangkan jika unsur sikap batin yang ditemukan berupa kesengajaan, maka kualifikasi perbuatan pidananya menjadi kejahatan.

\section{Pertanggungjawaban Bank Dalam Pelanggaran Kegiatan Operasional Didasarkan Pada Undang-Undang Nomor 10 Tahun 1998.}

Sebagaimana telah diuraikan pada pembahasan bagian A di atas, bahwa untuk dapat dipidananya seseorang atau badan hukum, haruslah terlebih dahulu memenuhi syarat pemidanaan. Oleh karena itu, apabila syarat sebagaimana dimaksud terpenuhi, maka sanksi sebagaimana dirumuskan dalam peraturan perundang-undangan terkait akan diberlakukan. Terhadap siapa pemidanaan itu akan diberlakukan, maka harus didasarkan atas subjek hukum mana yang telah melakukan tindak pidana, mengingat sifat dari hukum pidana terkait pembebanan pidana ditujukan langsung kepada pelaku, meskipun dimungkin adanya pembebanan lain terhadap pihak-pihak yang memiliki keterkaitan khusus dengan pengelolaan bank.

Apabila mengkaji subjek hukum dalam rumusan Pasal 48 ayat (2) Undang-Undang Nomor 10 Tahun 1998 juncto UndangUndang Nomor 7 Tahun 1992 tentang Perbankan, maka subjek hukum dalam pasal sebagaimana dimaksud terdiri atas; Anggota Dewan Komisaris, Direksi, atau pegawai bank, sehingga apabila salah satu dari subjek hukum tersebut melakukan tindak pidana (pelanggaran), maka pembebanan pidana secara langsung ada pada subjek hukum dimaksud. Namun demikian, meskipun pembebanan pidana langsung dikenakan kepada subjek hukum yang melakukan tindak pidana, bukan berarti bank tidak dapat bertanggungjawab secara administratif maupun perdata, apabila tindak pidana yang dilakukan subjek hukum tersebut berdampak pada kerugian pihak lain. Hal ini didasarkan pada Teori Pertanggungjawaban Pengganti (Vicarious Liability). Pertanggungjawaban pidana pengganti adalah pertanggungjawaban atas tindakan orang lain (a vicarious liability is one where in one person, thought without personal fault, is more liable for the conduct of another). Ditinjau dari aspek perdata tindakan yang menimbulkan kerugian terhadap pihak lain dianggap suatu Perbuatan Melawan Hukum. Perbuatan Melawan Hukum Indonesia yang berasal dari Eropa Kontinental diatur dalam Pasal 1365 KUHPerdata sampai dengan 1380 KUHPerdata. Salah satu bentuk perbuatan melawan hukum yang dikenal berdasarkan Pasal-pasal tersebut tidak hanya perbuatan melawan hukum yang dilakukan sendiri, tetapi juga berkenaan dengan perbuatan melawan hukum orang lain dan barang-barang di bawah pengawasannya, 
sebagaimana diatur dalam Pasal 1367 ayat

(1) KUHPerdata:

" Seorang tidak saja bertanggung jawab untuk kerugian yang disebabkan perbuatannya sendiri, tetapi juga untuk kerugian yang disebabkan perbuatan orang-orang yang menjadi tanggungannya atau disebabkan oleh barang-barang yang berada di bawah pengawasannya."

Berdasarkan Pasal 1367 ayat (1) KUHPerdata, yang merupakan rumusan umum, maka pertanggung jawaban dibagi menjadi: ${ }^{1}$

1. Tanggung jawab terhadap perbuatan orang lain

a. tanggung jawab atas perbuatan yang dilakukan oleh orang yang menjadi tanggungannya secara umum;

b. tanggung jawab orang tua dan wali terhadap anak-anak yang belum dewasa (Pasal 1367 ayat (2) KUHPerdata);

c. tanggung jawab majikan dan orang yang mewakilkan urusannya terhadap orang yang dipekerjakannya (Pasal 1367 ayat (3) KUHPerdata);

d. tanggung jawab guru sekolah dan kepala tukang terhadap murid dan tukangnya (Pasal 1367 ayat (4) KUHPerdata).

2. Tanggung jawab terhadap barang pengawasannya

Rosa Agustina, Perbuatan Melawan Hukum, Jakarta: Universitas Indonesia, Fakultas Hukum, Pascasarjana, 2003, hlm 11-12. a. tanggung jawab terhadap barang pada umumnya (Paal 1367 ayat (1) KUHPerdata);

b. tanggung jawab terhadap binatang (Pasal 1368 KUHPerdata);

c. tanggung jawab pemilik terhadap $\begin{array}{lll}\text { gedung } \quad \text { (Pasal } & 1369\end{array}$ KUHPerdata)

Pada praktik perbankan, bank bertanggungjawab atas perbuatan yang dilakukan oleh Komisaris, Direksi, Pemilik maupun Pegawai Bank bersangkutan. Adapun pertanggungjawaban didasarkan pada teori badan hukum, dengan asumsi bahwa bank yang beroperasi di Indonesia merupakan suatu badan hukum, di mana suatu badan hukum bertanggungjawab atas perbuatan yang dilakukan oleh orang yang menjadi tanggungannya secara umum maupun tanggung jawab majikan dan orang yang mewakilkan urusannya terhadap orang yang dipekerjakannya. Terdapat beberapa teori hukum yang mengakui kehadiran badan hukum sebagai subjek hukum, di samping manusia: ${ }^{2}$

Namun, fakta lain dapat menunjukkan bahwa bank sebagai korporasi dapat secara langsung melakukan tindak pidana melalui individu, pihak-pihak atau organ-organ lainnya, dengan kata lain bahwa bank sebagai korporasi melakukan tindak pidana yang menimbulkan kerugian besar. Untuk itu pembebanan pidana ada pada korporasi. Hal ini didasarkan pada Teori Pertanggungjawaban Korporasi. Menurut doktrin ini, perusahaan dapat melakukan

\footnotetext{
${ }^{2}$ Rachmadi Usman, Aspek-Aspek Hukum Perorangan dan Keluarga di Indonesia, Jakarta: Sinar Grafika, 2006, hlm 94-97.
} 
sejumlah delik secara langsung melalui orang-orang yang sangat berhubungan erat dengan perusahaan dan dipandang sebagai perusahaan itu sendiri. Dalam keadaan demikian, mereka tidak sebagai pengganti, dan oleh karena itu pertanggungjawaban perusahaan tidak bersifat pertanggungjawaban pribadi. ${ }^{3}$ Doktrin ini merupakan dasar pertanggungjawaban korporasi terhadap tindak pidana. Oleh karena itu dikemukakan, bahwa perusahaan bertanggungjawab atas tindak pidana yang dilakukan oleh pejabat senior di dalam perusahaan sepanjang ia melakukannya dalam ruang lingkup kewenangan atau dalam urusan transaksi perusahaan. ${ }^{4} \mathrm{Di}$ samping dikenakan pembebanan pidana, bank sebagai korporasi dapat dikenakan sanksi administratif sebagaimana dimaksud dalam Pasal 52 Undang-Undang Nomor 10 Tahun 1992 tentang Perubahan Atas Undang-Undang Nomro 7 Tahun 1992 tentang Perbankan

Pasal 52:

(1) Dengan tidak mengurangi
ketentuan pidana sebagaimana
dimaksud dalam Pasal 47, Pasal
47A, Pasal 48,Pasal 49, dan
Pasal 50A, Bank Indonesia dapat
menetapkan sanksi administratif
kepada bank yang tidak
memenuhi kewajibannya
sebagaimana dimaksud dalam
Undang-Undang ini, atau
Pimpinan Bank Indonesia dapat

\footnotetext{
${ }^{3}$ Barda Nawawi Arief, Sari Kuliah Perbandingan Hukum Pidana. Jakarta: Raja Grafindo Persada, 2002

${ }^{4}$ Christopher Ryan, Criminal Law, 5th Edition. London: Balckstone Press Limited, 1998, hlm 122.
}

mencabut izin usaha bank yang bersangkutan.

(2) Sanksi administratif sebagaimana dimaksud dalam ayat (1), antara lain adalah:

a. Denda uang;

b. Teguran tertulis;

c. Penurunan tingkat kesehatan bank;

d. Larangan untuk turut serta dalam kegiatan kliring;

e. Pembekuan kegiatan usaha tertentu, baik untuk kantor cabang tertentu maupun untuk bank secara keseluruhan;

f. Pemberhentian pengurus bank dan selanjutnya menunjuk dan mengangkat pengganti sementara sampai Rapat Umum Pemegang Saham atau Rapat Anggota Koperasi mengangkat pengganti yang tetap dengan persetujuan Bank Indonesia;

g. Pencantuman anggota, pengurus, pegawai bank, pemegang saham dalam daftar orang tercela di bidang Perbankan.

(3) Pelaksanaan lebih lanjut mengenai sanksi administratif ditetapkan oleh Bank Indonesia."

Sampai saat ini, pemidanaan terhadap bank masih belum dapat dilakukan karena dianggap bertentangan dengan asas legalitas. 
Perangkat hukum di Indonesia masih menetapkan subjek tindak pidana perbankan terbatas pada orang yakni pegawai, pengurus atau pejabat bank. Pemidanaan terhadap bank juga dikhawatirkan dapat mengganggu stabilitas ekonomi.

Diperlukan pengaturan lebih lanjut dan lebih rinci mengenai batasan dan syarat yang harus dipenuhi dalam hal sanksi pidana akan dijatuhkan pada Bank. Dalam hal perbuatan dikualifikasikan hanya sebagai pelanggaran, maka berdasarkan prinsip ultimum remedium, sanksi pidana sebaiknya tidak dijatuhkan pada korporasi. Jenis sanksi pidana yang dapat dijatuhkan pada bank atas terjadinya tindak pidana yang berdampak masif bagi masyarakat juga harus ditetapkan secara selektif. Alternatif sanksi pidana pokok yang dapat dijatuhkan pada bank adalah sanksi denda dan/atau pencabutan izin usaha, dan sanksi pidana tambahan berupa pengumuman putusan hakim untuk memberikan efek jera bagi bank yang melakukan tindak pidana.

\section{KESIMPULAN}

Berdasarkan uraian pembahasan di atas, maka dapat disimpulkan hal-hal sebagai berikut:

1. Undang-undang Perbankan mengkualifikasikan suatu tindakan sebagai pelanggaran sebagaimana dinyatakan dalam rumusan peraturan perundang-undangan, berdasarkan unsur sikap batin kelalaian. Untuk dapat dijatuhkannya sanksi pidana, pelaku, baik individu maupun organ bank memenuhi unsur-unsur tertulis yang tercantum dalam rumusan delik tersebut. Adapun pembebanan pidana terhadap pelaku atas terpenuhinya unsur-unsur sebagaimana dimaksud, harus memenuhi syarat pemidanaan yang terdiri atas syarat objektif maupun subjektif.

2. Pembebanan pidana akan dikenakan secara langsung terhadap subjek hukum yang melakukan tindak pidana pelanggaran, namun hal ini berlaku apabila subjek hukum sebagaimana dimaksud bertindak bukan mewakili kepentingan bank sebagai korporasi. Untuk hal tersebut, maka bank dapat dikenakan sanksi perdata maupun sanksi administratif. Namun apabila tindak pidana dilakukan oleh subjek hukum sebagaimana dimaksud, merupakan tindakan yang mewakili kepentingan bank sebagai korporasi secara langsung, maka pembebanan pidana seharusnya dapat dikenakan langsung kepada korporasi.

Dalam penelitian ini, penulis juga menyarankan:

1. Perlu pengawasan yang optimal dari Otoritas Jasa Keuangan terhadap pengelolaan bisnis perbankan, mengingat tindak pidana kejahatan maupun pelanggaran dalam bisnis perbankan berkembang secara dinamis, serta perlu adanya penguatan substansi untuk menjangkau modus baru tindak pidana yang saat ini tidak terjangkau oleh Undang-Undang Nomor 10 Tahun 1998 tentang Perubahan Atas Undang-Undang Nomor 7 Tahun 1992 tentang Perbankan, seperti misalnya jual beli data nasabah. 
2. Perlu upaya peningkatan kemampuan sumber daya manusia, seperti Direksi, Komisaris, dan Pegawai Bank tentang Hukum Perusahaan, Hukum Perbankan dan Hukum Pidana, agar dalam menjalankan tugas dan kewenangannya tidak melakukan tindak pidana, baik kejahatan maupun pelanggaran.

3. Perlu regulasi terkait penjatuhan sanksi pidana bagi bank yang melakukan tindak pidana (kejahatan) yang menimbulkan kerugian yang serius bagi masyarakat.

\section{DAFTAR PUSTAKA}

\section{Buku dan Karya Ilmiah}

A.H. Semendawai. Tanggung Jawab Pidana Korporasi Dalam RUU KUHP. Jakarta: Lembaga Studi Advokasi Masyarakat, 2005.

Ahmad Fuad, Penegakan Hukum dan Upaya Pencegahan terhadap Kejahatan Perbankan. Seminar Nasional Penegakan Hukum dan Upaya Pencegahan terhadap Kejahatan Perbankan, Bandung: Sekolah Tinggi Hukum Bandung, 2011.

Ali Rido. Badan Hukum Dan Kedudukan Badan Hukum Perseroan, Perkumpulan, Koperasi, Yayasan. Wakaf. Alumni, Bandung, 2004.

Bambang Poernomo. Asas-asas Hukum Pidana. Jakarta: Balai Aksara, 1994.
Barda Nawawi Arief. Sari Kuliah Perbandingan Hukum Pidana. Jakarta: RajaGrafindo Persada, 2002.

Chidir Ali. Badan Hukum. Bandung: Alumni, 1989.

Christopher Ryan. Criminal Law. 5th Edition. London: Balckstone Press Limited, 1998, hlm 122.

E. Utrecht. Hukum Pidana I. Jakarta: Universitas, 1958.

Hilman Hadikusuma. Metode Pembuatan Kertas Kerja atau Skripsi Ilmu Hukum. Bandung: Mandar Maju, 1995.

I Made Widnyana. Asas-Asas Hukum Pidana. Jakarta: Fikahati Aneska, 2010.

Johannes Ibrahim. Bank Sebagai Lembaga Intermediasi dalam Hukum Positif. Bandung: Utomo, 2004.

Marjono Reksodiputro. Kemajuan Pembangunan Ekonomi dan Kejahatan, Kumpulan Karangan Buku Kesatu. Jakarta: Pusat Pelayanan Keadilan dan Pengabdian Hukum, 1994.

Moeljatno. Asas-Asas Hukum Pidana Indonesia. Jakarta: Rineka Cipta, 2002.

Mudrajad Kuncoro et.al. Manajemen Perbankan Teori dan Aplikasi. Yogyakarta: BPFE, 2002. 
Muhamad Djumhana. Asas-asas Hukum Perbankan Indonesia. Bandung: Citra Aditya Bakti, 2008.

Muladi dan Barda Nawawi Arief. TeoriTeori dan Kebijakan Pidana. Bandung: Alumni, 2005.

Muladi dan Dwidja Priyatno. Pertanggungjawaban Pidana Korporasi. Jakarta: Prenada Media Group, 2010.

P.A.F Lamintang. Dasar-Dasar Hukum Pidana Indonesia. Bandung: Sinar Baru, 1984.

Peter Mahmud Marzuki. Penelitian Hukum. Jakarta: Kencana, 2005

R. Abdoel Djamali. Pengantar Hukum Indonesia. Jakarta: Raja Garafindo Persada, 2000.

R. Edward Freeman. Manajemen Strategik, Pendekatan Terhadap Pihak-Pihak Berkepentingan. Jakarta: Pustaka Binaman Presindo, 1985.

Rachmadi Usman. Aspek-Aspek Hukum Perorangan dan Keluarga di Indonesia. Jakarta: Sinar Grafika, 2006.

Rosa Agustina. Perbuatan Melawan Hukum. Jakarta: Universitas Indonesia, Fakultas Hukum, Pascasarjana, 2003.
R. Soeroso. Perbandingan Hukum Perdata. cet ke 7. Jakarta: Sinar Grafika, 2007.

RA. Supriyono. Manajemen Strategi dan Kebijaksanaan Bisnis. Yogyakarta: BPFE, 1990.

Sutan Remi Sjahdeini. Sutan Remi Sjahdeini. Pertanggungjawaban Pidana Korporasi. Jakarta: Grafiti Pers, 2006.

Thomas Suyatno. Kelembagaan Perbankan. Jakarta: Gramedia Pustaka Utama, 1993.

Wirjono Prodjodikoro. Tindak-Tindak Pidana Tertentu Di Indonesia. Bandung: Refika Aditama, 2003.

Yunus Husein. Penerapan Prinsip Mengenal Nasabah oleh Bank dalam Rangka Penanggulangan Kejahatan Money Launderying. Jurnal Hukum Bisnis Volume 16, November 2001.

\section{Peraturan Perundang-undangan}

Kitab Undang-Undang Hukum Perdata

Kitab Undang-Undang Hukum Pidana

Undang-Undang Nomor 7 Tahun 1992 tentang Perbankan.

Undang-Undang Nomor 10 Tahun 1998 tentang Perubahan Atas UndangUndang Nomor 7 Tahun 1992. 
Peraturan Bank Indonesia Nomor

3/10/PBI/2001 tentang Penerapan

Prinsip Mengenal Nasabah.

Peraturan Bank Indonesia Nomor 11/25/PBI/2009 tentang Perubahan Atas Peraturan Bank Indonesia

Nomor 5/8/PBI/2003 tentang

Penerapan Manajemen Risiko Bagi

Bank Umum. 